\title{
THE REMITTANCES AS A POTENTIAL ECONOMIC GROWTH RESOURCE FOR ROMANIA
}

\author{
Zizi Goschin ${ }^{1}$
}

\begin{abstract}
As an important emigration country, Romania benefits from significant remittance inflows that sustained the increased domestic consumption and may have also contributed to the strong economic growth prior to the recent economic crisis. Our empirical research aimed to investigate, by means of multi-factorial regression models, the contribution of the remittances to the long-term economic growth in Romania. The main result of our research is a significant positive impact of remittance inflows on the economic growth in Romania over 1994-2011.
\end{abstract}

Keywords: remittances, economic growth, Romania

JEL Codes: C51, F22

\section{Introduction}

International and national statistics indicate that Romania is an important emigration country, as the number of Romanians living abroad has reached about 3 million persons. In addition Romania has long been an important recipient of remittances that sustained increased domestic consumption and contributed to strong economic growth since 2000, while reducing the current account deficits. According to the World Bank data (World Bank, 2011), the money transfers from abroad towards Romania have been on a step upward trend since 2000 and reached a peak of $9.3^{2}$ billion $\$$ in 2008, representing the largest remittances received by an EU country. As a consequence of the global crisis, remittances have been constantly falling, leveling to 3.9 billion \$ (2\% of GDP) in 2011.

Depending on their concrete use, the remittance flows either provide additional revenues for household consumption or are invested. Invested remittances become direct sources of capital that foster the economic growth of the receiving countries from the supply side, while the remittances used for household consumption can also fuels the economic growth from the demand side, as they increase the aggregate demand. Moreover, at the macroeconomic level, remittances might have a major contribution in financing the current account deficit. For instance, Daianu et al (2001) demonstrated that the absence of remittances would have caused unsustainable deficits in Romania.

Since remittances received are a potential source of investments and are therefore able to bring about concrete economic benefits, estimating their macroeconomic effects is an issue of both economic and politic interest. The macroeconomic effects of remittances and especially their economic growth potential have been under-researched in Romania. Consequently, our research objective is to investigate, through multiple regression models, the contribution of the remittances received in Romania to its long-term economic growth.

The structure of this paper is as follows. Section two briefly reviews the relevant empirical literature on the links between remittances and economic growth. Section three presents the research design and methodology we are to use in our research, alongside the selected economic

\footnotetext{
${ }^{1}$ Institute of National Economy, Academy of Economic Studies, Bucharest, Romania,e-mail: zizi.goschin@csie.ase.ro

${ }^{2}$ The National Bank of Romania estimated an amount of 11.4 billion $\$$ for the same year.
} 
variables. Section four discusses the results from estimation of the econometric models, while section five concludes.

\section{Literature review}

The remittances, representing money transfers from the emigrants to the families back home, are a potential marked factor of economic development that attracts constant attention in the empirical studies. From an economic perspective, the strongest impact that emigration has on the countries of origin is conveyed through remittances. The money sent home by the migrant workers are important both for the receiving households and for the economy as a whole. Remittances are an important source of external funding that can boost economic growth in developing countries. They rank second to foreign direct investments and are much bigger than the official development assistance (de Haas, 2012).

The actual contribution of remittances to economic growth is a subject of debate in the literature. There exist empirical studies that found a positive effect of remittances on economic growth (e.g. Jongwanich, 2007), while others reported a negative influence (Chami et al, 2005) or no impact at all (Mallick, 2008). Such opposite results originate in inter-country differences regarding the concrete use of the money transfers from abroad, as the remittances may go to consumption, to investments or both, depending on a variety of factors specific to the receiving family and to the national economy.

The amount of remittances destined for investment directly impacts job creation, expansion of productive activities and finally the economic growth (from the supply side). The appropriate economic environment and policies could also foster the propensity to invest. Even if remittances are largely destined for consumption (e.g. Fullenkamp, 2003; Jongwanich, 2007), they can also impact economic growth (from the demand side), as increased household consumption stimulates production of goods and services (Katseli et al, 2006), but the influence would be indirect and weaker.

Many studies undertaken in Romania indicate that the biggest part of the remittances goes to consumption and construction/modernisation of houses, leaving only a small amount to be invested (e.g. Noica and Stoiciu, 2006; Grigoraş, 2006; Lăzăroiu and Alexandru, 2008). On the contrary, other empirical studies indicated a positive effect of remittances on the investments made in Romania (Litan, 2009; Soros Foundation Romania, 2011; Încalțărău and Maha, 2012). This second group of studies found a high propensity to invest money from abroad, which can be explained by the use of data coming from official sources. Since the formal channels are safer, they are used to transfer the large sums of money needed for investments, while smaller amounts can be send through informal channels such as friends or relatives. There is evidence that a considerable share of remittances is transferred through informal means. For instance, Lazaroiu and Alexandru (2008) showed that approximately 40 per cent of the transfers are made through informal channels.

Many studies on Romanian migration were based on surveys analysis (De Sousa and Duval, 2010; Roman and Voicu, 2010; Soros Foundation Romania, 2011; Goschin and Roman, 2012). There have also been made attempts to estimate the macroeconomic impact of migration and remittances (e.g. Litan, 2009; Constantin et al., 2009; Încalțărău and Maha, 2012). We aim to contribute to this second line of research by investigating the influence that the remittances received might have had on the long-term economic growth in Romania.

\section{Research design and methodology}

Our search for proofs in favour of the hypothesis of remittances as a source of economic growth in Romania is based on multi-factorial regression models. The main focus in these models is on the potential relationship between GDP as an exogenous (dependent) variable and remittances, our variable of interest, as exogenous (dependent) variable. According to economic theory and econometric practice, several other independent variables (production factors) have to be included 
in the models as control variables. Tables 1 and 2 display all the variables included in the regression models that we are going to test.

Table no. 1.

The variables for model 1 (dependant variable-GDP)

\begin{tabular}{|l|l|}
\hline \multicolumn{1}{|c|}{ Variable name } & \multicolumn{1}{c|}{ Description } \\
\hline GDP & GDP (US\$) \\
\hline GFCF & Gross fixed capital formation (US\$) \\
\hline Ter_educ\% & Labor force with tertiary education (\% of total) \\
\hline Labor & Labor force, total (persons) \\
\hline RD\% & $\begin{array}{l}\text { Research and development expenditure (\% of } \\
\text { GDP) }\end{array}$ \\
\hline Rural & Rural population (\% of total population) \\
\hline Trade & Trade (\% of GDP) \\
\hline Remit & Personal remittances, received (US\$) \\
\hline FDI & Foreign direct investment, net inflows (US\$) \\
\hline
\end{tabular}

Table no. 2 .

The variables for model 2 (dependant variable - annual GDP growth)

\begin{tabular}{|l|l|}
\hline Variable name & Description \\
\hline GDP_gr & GDP growth (\%) \\
\hline Empl_agric & $\begin{array}{l}\text { Employment in agriculture as percentage of total } \\
\text { employment (\%) }\end{array}$ \\
\hline FDI\% & $\begin{array}{l}\text { Foreign direct investment, net inflows (as percentage of } \\
\text { GDP) }\end{array}$ \\
\hline Remit\% & Personal remittances, received (\% of GDP) \\
\hline GFCF\% & Gross fixed capital formation (\% of GDP) \\
\hline GFCF_gr & Gross fixed capital formation (annual \% growth) \\
\hline Labor_p & $\begin{array}{l}\text { Labor force participation rate, total (\% of total } \\
\text { population ages 15-64) }\end{array}$ \\
\hline Ter_educ\% & Labor force with tertiary education (\% of total) \\
\hline RD\% & Research and development expenditure (\% of GDP) \\
\hline Rural\% & Rural population (\% of total population) \\
\hline Trade\% & Trade (\% of GDP) \\
\hline
\end{tabular}

The general specification of the linear multiple regression models to be further estimated is as follows:

$$
\boldsymbol{Y}_{t}=\boldsymbol{\beta}_{0}+\Sigma_{j} \boldsymbol{\beta}_{j} \boldsymbol{K}_{t j}+\varepsilon_{t},
$$

where $\boldsymbol{Y}_{t}$ represents the dependent variable (GDP and GDP growth, respectively), $\boldsymbol{K}_{t i j}$ are the exogenous variables, $\boldsymbol{\beta}_{j}$ are the parameters that summarize the $j$ factor contribution to the dependent variable, while $t$ stands for the year. Last, $\varepsilon_{t}$ is an independently and identically distributed error term with zero mean and constant variance $\sigma^{2}$. The regression models allow for estimation of GDP changes when remittances vary, the other independent variables being constant.

The data for our analysis were drawn from the World Bank online database. Given the lack of data on remittances prior to 1994, the analysis' time span is limited to the $1994-2011$ interval.

Prior to models' estimation we have to perform a statistical analysis of the variables of interest, including a test to detect the likely non-stationary variation of the time series data. A process is stationary if it fluctuates around its mean. The presence of a trend, which is frequent in time-series data, results in non-stationarity and raises potentially detrimental estimation issues. 
When non-stationary variables are regressed on each other, the estimation based on OLS is not valid. The results from OLS may indicate in this case relationships that do not hold, estimates void of economic meaning, despite high R-square levels. This is the so-called 'spurious regression' issue (Granger, 1974).

The stationarity of the time series data can be tested applying a unit root test. When the "unit root" is detected a common solution is to transform the variable using the difference operator until the test indicates no unit root. For most series the first difference operator $\left(\Delta \mathrm{X}_{t}=\mathrm{X}_{\mathrm{t}}-\mathrm{X}_{\mathrm{t}-1}\right)$ will suffice to eliminate the unit root. Such time series are called first-order integrated series (I(1)). The new time series obtained by differencing are stationary and OLS can be safely used for further estimations.

Sometimes the relation between unit root processes is not spurious, but true if there exists a linear combination of them that is stationary. In this case the variables are said to be cointegrated. Cointegration of two variables is considered proof of a long-term relationship between them. Identifying a cointegrating relationship between variables is useful for the analysis, especially if the time series are relatively short, as is our case. Therefore we are going to apply the Johansen test (Johansen, 1991) to check for the potential cointegration between GDP and remittances, as well as for GDP growth and remittances growth. The presence of cointegration would support the hypothesis of remittances as a source of economic growth in Romania.

\section{Results and discussion}

The parameters of the models were estimated in EViews 7, using Ordinary Least Squares (OLS). The first model regressed GDP (US\$) on personal remittances received (US\$), gross fixed capital formation (US\$), FDI (US\$) and other control variables (see table 2 for the complete list). Table 3 presents the results from this model, excluding the variables that are not statistically significant, except for remittances that is our variable of interest. Although the amount of remittances received by the Romanian families is high, model 1 fails to bring support to the hypothesis of remittances as an investment channel. This may be explained by the use of remittances for household consumption foremost, but it can also be a problem of model specification that will be addressed later.

Both domestic and foreign capital (gross fixed capital formation and inflows of foreign direct investment) are positive and significant, as expected.

Considering the constant decline in employment since 1990, it is not surprising that the variable total labor force does not have a significant influence on GDP. It is noteworthy that the reduction in labor force is compensated by an increase in human capital and by higher productivity. Labor force with tertiary education (\% of total) seems to have a positive and highly significant impact on GDP.

Research and development expenditure (\% of GDP) is significant and have the expected positive sign, although the estimated coefficient is very small, suggesting that the research potential is not properly used.

Rural population seems to have a positive influence on GDP, as its share in total population expanded. The high rural-urban migration flows during the communist regime reversed since 1990, following economic restructuring and rise in unemployment. The increased rural population does indeed contribute to economic growth, but at low productivity levels specific to the subsistence agriculture mainly providing for basic needs of the family. 


\begin{tabular}{|c|c|c|c|}
\hline \multicolumn{4}{|c|}{ Regression results - model 1(dependant variable-GDP) } \\
\hline Variable & Coefficient & Std. Error & Prob. \\
\hline REMIT & 0.033163 & 0.316528 & 0.9184 \\
\hline$\overline{\text { GFCF }}$ & 1.780624 & 0.196602 & 0.0000 \\
\hline FDI & 0.892318 & 0.190790 & 0.0005 \\
\hline TER_EDUC\% & $9.79 \mathrm{E}+08$ & $2.44 \mathrm{E}+08$ & 0.0021 \\
\hline LABOR & 1169.433 & 998.3230 & 0.2662 \\
\hline $\mathrm{RD} \%$ & $5.14 \mathrm{E}+10$ & $1.49 \mathrm{E}+10$ & 0.0055 \\
\hline RURAL & $3.08 \mathrm{E}+10$ & $6.62 \mathrm{E}+09$ & 0.0007 \\
\hline $\mathrm{C}$ & $-1.45 \mathrm{E}+12$ & $3.23 \mathrm{E}+11$ & 0.0009 \\
\hline Adjusted R-squared & & 0.970041 & \\
\hline F-statistic & & 130.5170 & \\
\hline Prob(F-statistic) & & 0.000000 & \\
\hline Durbin-Watson stat & & 2.047159 & \\
\hline
\end{tabular}

Table no. 3 .

Source: author's calculations.

Statistical analysis of the data detected the presence of a "unit root", i.e. non-stationary variation, for all the variables in the model, based on the results from the Johansen test. Consequently, we further ran OLS regressions on differenced data for our variables. The results are displayed in Table 4. Only the statistically significant variables have been included in the final specification of the model.

Table no. 4.

Regression results for model 1 with differenced variables (dependant variable- D(GDP))

\begin{tabular}{|c|c|c|c|}
\hline Variable & Coefficient & Std. Error & Prob. \\
\hline D(REMIT-1) & 0.240932 & 0.118495 & 0.0725 \\
\hline $\mathrm{D}(\mathrm{GFCF})$ & 0.996328 & 0.156282 & 0.0007 \\
\hline $\mathrm{D}(\mathrm{FDI})$ & 0.257478 & 0.089174 & 0.0234 \\
\hline D(LABOUR) & -5833.227 & 2263.986 & 0.0299 \\
\hline D(TER_EDUC\%) & $6.31 \mathrm{E}+08$ & $2.47 \mathrm{E}+08$ & 0.0510 \\
\hline $\mathrm{D}(\mathrm{RD} \%)$ & $5.35 \mathrm{E}+10$ & $1.61 \mathrm{E}+10$ & 0.0211 \\
\hline D(RURAL) & $2.49 \mathrm{E}+10$ & $7.61 \mathrm{E}+09$ & 0.0221 \\
\hline D(TRADE) & -82601629 & 56139177 & 0.1916 \\
\hline $\mathrm{C}$ & $7.17 \mathrm{E}+08$ & $2.94 \mathrm{E}+08$ & 0.0373 \\
\hline Adjusted R-squared & 0.903060 & & \\
\hline F-statistic & 27.08375 & & \\
\hline Prob(F-statistic) & 0.000036 & & \\
\hline Durbin-Watson stat & 1.826646 & & \\
\hline
\end{tabular}

Notes: 1. $\mathrm{D}(\mathrm{X})$ stands for the first difference for variable $\mathrm{X} ; 2$. Highly correlated variables, such as gross fixed capital formation and FDI, or labor and labor force with tertiary education ( $\%$ of total) have been estimated in separate models to avoid multicollinearity.

Source: author's calculations.

The new results are quite different: most important, the variable of interest -remittances- is now statistically significant, supporting the hypothesis of remittance inflows being a relevant factor of economic growth in Romania for the last two decades. This is in line with other empirical studies that reported remittances' potential to boost economic growth, especially in developing countries (Giuliano and Ruiz-Arranz, 2009; Încalțărău and Maha, 2012). Since remittances are expected to act as investments, a one year lag was applied in order to better capture their economic impact. 
According to the theory, we also tested one year lag for foreign direct investments and two and three-year lag for research and development investments. Surprisingly, the lagged FDIs and $R \& D$ are both insignificant regressors in our model, while their contemporaneous values seem to be highly significant explanatory variables for GDP.

Other positive and significant factors of influence for GDP are the gross fixed capital formation, rural population ( $\%$ of total population) and labor force with tertiary education ( $\%$ of total). The labor force is now significant both in its quantitative (number of persons) and qualitative form (\% of tertiary education), but the former coefficient bears a negative sign, while the latter is positive. This negative sign can be explained by the long-term decline in employment, even during economic growth. Although decreasing on the long-run, the Romanian labor force is becoming more efficient as it is better-educated and its productivity is on the rise, driving the growth of GDP.

The model is statistically significant and explain in a very large proportion the variability of GDP (adjusted $\mathrm{R}^{2}=0.9$ ). The standard econometric tests also yield good results: we checked for autocorrelation of errors (Durbin-Watson statistic and Breusch-Godfrey Serial Correlation LM Test), heteroscedasticity (Breusch-Pagan-Godfrey and White tests), normal distribution of errors (Jarque Bera normality test). Since some variables are highly correlated (for instance gross fixed capital formation and FDI, as well as labor and labor force with tertiary education), their coefficients have been estimated in separate models to avoid multicollinearity.

Another group of models was used to estimate GDP annual growth depending on the remittances received (\% of GDP), gross fixed capital formation (annual \% growth) and other control variables (see table 2 for the complete list of variables included in this model). Since most of the variables, including remittances as percentage of GDP, are not statistically significant, we are not going to report the results from the GDP annual growth model.

Summing up, our analysis found a significant impact of remittance inflows on the economic growth in Romania over 1994-2011, confirming our expectations regarding their important macroeconomic role.

\section{Conclusion}

Depending on their concrete destination, the remittance flows are used either as additional revenue for household consumption or as investments. Either way they can impact economic growth from the demand side or from the supply side.

Based on the estimations from several multi-factorial regression models, our analysis found a significant impact of remittance inflows on the economic growth in Romania over 1994-2011. This is confirming our research hypothesis, as well as the findings from previous studies regarding the macroeconomic role of remittances as development factor.

Since a favourable economic environment can foster the propensity to invest, appropriate policies should be devised to better exploit the investment potential of remittances, as one of the engines of economic growth in Romania.

\section{References}

1. Chami, R., Fullenkamp, C., Jahjah, S., 2005. Are Immigrant Remittance Flows a Source of Capital for Development?, IMF Staff Papers vol. 52, no. 1, pp. 55-81.

2. Fullenkamp, C., Jahjah, S. 2003. Are Immigrant Remittance Flows a Source of Capital for Development?, IMF Working Paper 03/189 (Washington: International Monetary Fund).

3. Constantin D.L, Nicolescu L., Goschin, Z. 2009. "European perspectives for approaching asylum and migration"/ "Perspective europene de abordare a azilului şi migrației”, ediție bilingvă - română şi engleză), SPOS Project - Strategy and Policy Studies, European Institute of Romania, Bucharest 
4. Daianu D., Voinea L., and Tolici M. 2001. Balance of Payments Financing in Romania. The Role of Remittances. The Romanian Center for Economic Policies Working Paper No. 28, The Romanian Center for Economic Policies, Bucharest.

5. De Haas H., 2012. The Migration and Development Pendulum: A Critical View on Research and Policy, International Migration, Vol. 50, Issue 3, pp. 8-25

6. De Sousa, J. and L. Duval, 2010. Geographic distance and remittances in Romania: Out of sight, out of mind?, Economie internationale, Vol.121, No.1.

7. Giuliano, P., Ruiz-Arranz, M. 2009. Remittances, financial development, and growth, Journal of Development Economics, Volume 90, Issue 1, pp. 144-152

8. Goschin Z., Popa A., Roman M., 2010. Romanian Migrants' Remittances: Past Trends and Short-term Prospects, Analele Universității Ovidius, Seria: Ştiințe economice, Vol. X, nr. 2/2010, pp. 293-297.

9. Goschin Z., Roman M., 2012. Determinants of the Remitting Behaviour of Romanian Emigrants in an economic crisis context, Eastern Journal of European Studies, vol. 2, no.1, pp.87-103.

10. Granger C. W. J., Newbold P., 1974. Spurious regressions in econometrics, Journal of Econometrics, vol. 2, no.2, pp. 111-120.

11. Grigoraş V., 2006. Consecințe şi proiecte - Venituri şi investiții din migrație in Sandu, D. (ed) Locuirea temporară în străinătate. Migrația economică a românilor: 1990-2006, Fundația pentru o Societate Deschisă

12. Încalțărău C., Maha L.G, 2012. The impact of remittances on consumption and investment in Romania, Eastern Journal of European Studies, Volume 3, Issue 2, pp. 61-86

13. Johansen S., 1991. Estimation and Hypothesis Testing of Cointegration Vectors in Gaussian Vector Autoregressive Models, Econometrica, vol. 59, no 6, pp. 1551-1580.

14. Jongwanich J. 2007. Workers' Remittances, Economic Growth and Poverty in Developing Asia and the Pacific Countries, United Nations, Economic and Social Comission for Asia and the Pacific, Working Paper 07/01.

15. Katseli L. T., Lucas Robert E.B., Xenogiani T., 2006. Effects of Migration on Sending Countries: What Do We Know?, OECD Development Centre, Working Paper No. 250

16. Lăzăroiu S. and Alexandru M. 2008. Who is Coming after Who is Leaving? Labour Migration in the Context of Romania's Accession to the EU. Country Report. International Organization for Migration, Geneva.

17. Litan C. 2009. On the Macroeconomic Impact of Remittances in Romania, Studia Universitatis Babeş Bolyai, Oeconomica, Vol. 54, Issue 2, pp. 21-36.

18. Mallick H. 2008. Do Remittances Impact the Economy? Some Empirical Evidences from a Developing Economy, Working Paper 407, Centre for Development Studies, Trivandrum, India

19. Nicolae M., Radu, B. M., 2007. Socio-Economic Effects of the Labor Force Migration in an Enlarged Europe, Romanian Journal of Economic Forecasting, No. 2, pp. 54-73.

20. Noica R., Stoiciu V. 2006. Raport de cercetare pe tema migrației forței de muncă. Aspecte sociale şi instituționale ale fenomenului, Societatea Academica din Romania, available at http://www.sar.org.ro/files /Raport\%20Social.doc.

21. Roman M. and Voicu C. 2010. Some socio-economic effects of labour migration on sending country. Evidence from Romania, Theoretical and Applied Economics No. 7, pp. 61-76.

22. Schiopu I. and Siegfried N., .2006. Determinants of Workers' Remittances. Evidence from the European Neighbouring Region, Working Paper Series, 688.

23. Soros Foundation Romania, International Agency for Source Country Information .2011. Maximising the Development Impact of Migration, Research Overview, Selected Findings, Case Study.

24. Spatafora, N. 2005. Worker Remittances and Economic Development, World Economic Outlook, April, pp. 69-84.

25. World Bank, 2011. Migration and Remittances Factbook 2011, available at http://siteresources.worldbank.org/INTLAC/Resources/Factbook2011-Ebook.pdf.

26. World bank database, available at http://databank.worldbank.org/data/home.aspx 